\title{
Recurrent blooms of Heterosigma akashiwo (Raphidophyceae) in the Piraquê Channel, Rodrigo de Freitas Lagoon, southeast Brazil
}

\author{
Branco, S. ${ }^{a}$, Menezes, $M{ }^{a *}$, Alves-de-Souza, $C{ }^{a}{ }^{a}$, Domingos, $P^{b}$, \\ Schramm, MA. ${ }^{c}$ and Proença, LAO. ${ }^{c}$

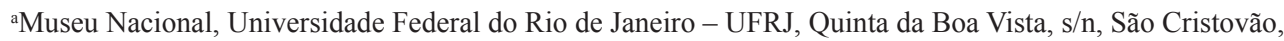 \\ CEP 20940-040, Rio de Janeiro, RJ, Brazil \\ 'Instituto de Biologia Roberto A. Gomes - IBRAG, Universidade Estadual do Rio de Janeiro - UERJ, \\ Rua São Francisco Xavier, 524, Maracanã, CEP 20550-900, Rio de Janeiro, RJ, Brazil \\ 'Instituto Federal de Educação, Ciência e Tecnologia de Santa Catarina, Av. Abraão João Francisco, 3899, \\ Ressacada, CEP 88307-303, Itajaí, SC, Brazil \\ *e-mail: menezes.mariangela@gmail.com
}

Received: June 4, 2012 - Accepted: April 30, 2013 - Distributed: August 31, 2014

(With 6 figures)

\begin{abstract}
Six blooms of Heterosigma akashiwo (Raphidophyceae) were observed from March 2007 through March 2008 in the Rodrigo de Freitas Lagoon, a semi-confined eutrophic system located in Rio de Janeiro state, southeast Brazil. Vegetative cells of H. akashiwo analysed by optical and electron microscopy showed morphology as described in the literature. The blooms $\left(2.8 \times 10^{4}\right.$ to $4 \times 10^{8}$ cell. $\left.\mathrm{L}^{-1}\right)$ were restricted to the middle section of the Piraque Channel, which is situated in the northeastern part of the lagoon and receives freshwater inflow. The salinity of subsurface water and the channel depth showed significant negative correlations with $H$. akashiwo abundances, and appeared to restrict the blooms to this compartment of the lagoon. No fish mortality was associated with the H. akashiwo blooms, nor were brevetoxins detected in a cell extract obtained from the bloom observed on 19 March 2007.
\end{abstract}

Keywords: morphology, taxonomy, blooms, urban coastal lagoon, Rio de Janeiro.

\section{Florações recorrentes de Heterosigma akashiwo (Raphydophyceae) no Canal do Piraquê, Lagoa Rodrigo de Freitas, sudeste do Brasil}

\section{Resumo}

Seis florações de Heterosigma akashiwo (Raphidophyceae) foram observadas em março de 2007 a março de 2008 na Lagoa Rodrigo de Freitas, um sistema semi-confinado eutrófico localizado no Rio de Janeiro (Sudeste do Brasil). As células vegetativas de H. akashiwo analisadas por microscopia óptica e eletrônica mostraram morfologia como descrito em literatura. As florações $\left(2.8 \times 10^{4} \mathrm{a} 4 \times 10^{8} \mathrm{cel} . \mathrm{L}^{-1}\right)$ foram restritas à zona intermédia do canal Piraquê, que se situa na parte nordeste da lagoa e recebe aporte de água doce. A salinidade da sub-superfície da água e a profundidade do canal apresentaram correlação negativa significativa com a abundância de $H$. akashiwo e parecem determinar a formação de florações restritas a este compartimento da lagoa. Não houve mortalidade de peixes durante as florações de $H$. akashiwo e não foi detectada a presença de brevetoxinas em um extrato celular obtido a partir da floração observada em 19 de março de 2007.

Palavras-chave: morfologia, taxonomia, florações, lagoa costeira urbana, Rio de Janeiro.

\section{Introduction}

Blooms of the ichthyotoxic raphidophyte Heterosigma akashiwo (Hada) Hada occur widely in coastal ecosystems at different latitudes, where they are frequently responsible for extensive losses to farmed and wild fish stocks (O'Halloran et al., 2006; Kempton et al., 2008). Adverse and allelopathic effects of $H$. akahiswo are also known for various marine invertebrates including copepods, ciliates, larvae and adults of oysters, shrimps, and scallops
(Connell et al., 1997; Keppler et al., 2005; Wang et al., 2006; Yu et al. 2010). Up to now, no toxic effects in humans have been reported. Although the cause of the adverse effects or the occasional toxins produced by H. akashiwo have not been properly characterised, the harmful mechanism seems to be related to excessive mucus secretion and the production of reactive oxygen species (ROS), which can damage the gills of fish and blocks the exchange of $\mathrm{O}_{2}$, 
resulting in asphyxiation and death (Nakamura et al., 1998; Ling and Trick, 2010). Although some studies of samples from blooms or from cultures have revealed the presence of brevetoxin-like compounds (Khan et al., 1997; Haque and Onoue, 2002), these toxins do not occur widely (Lewittus and Holland, 2003; Zhang et al., 2004). In any case, toxicity or harmful effects seem to vary among different ecotypes, and are also potentially affected by environmental conditions such as nutrient concentrations (Jack Rensel et al., 2010).

In Brazil, blooms of $H$. akashiwo were first reported in the estuarine complex of Paranaguá, state of Paraná in the southern part of the country, in March 2001 and later in November 2004, with cell concentrations up to $2.6 \times 10^{6}$ cells. $L^{-1}$ (Proença and Fernandes, 2004) and $0.5 \times 10^{6}$ cells. L $^{-1}$ (Mafra, 2005), respectively. The 2001 bloom at Paranaguá was associated with fish mortality, resulting in prohibition of fishing and shellfish harvesting for 25 days (Proença and Fernandes, 2004). A strain of H. akashiwo isolated from the same bloom was toxic to juveniles of the mysidacean Mysidopsis juniae da Silva, and inhibited the larval development of the mussel Perna perna Linnaeus (Mafra, 2005). In Santa Catarina state, other blooms of $H$. akashiwo occurred in the Balneário de Camboriu in August 2002, with $19 \times 10^{6}$ cells. L $^{-1}$ and chlorophyll $a$ values of $67 \mu \mathrm{g} \mathrm{L}^{-1}$; and an extensive bloom in Tijucas Bay in August 2007; in both events, no fish mortality was reported (Proença et al., 2011).

Recently, recurrent blooms of $H$. akashiwo have been observed in a confined zone of Rodrigo de Freitas Lagoon, a shallow coastal system located in the state of Rio de Janeiro in southeastern Brazil (Branco et al., 2010). In the present study, we characterised the morphology and ultrastructure of $H$. akashiwo cells observed during these blooms. The influence of some abiotic parameters, as well as the production of brevetoxins and their analogues were also investigated.

\section{Material and Methods}

\subsection{Study area}

The Rodrigo de Freitas Lagoon is a semi-confined eutrophic coastal lagoon, with recurring blooms, and fish kills that are usually associated with dissolved-oxygen depletion. This lagoon is located in the southern part of the city of Rio de Janeiro (22 $57^{\prime} 02$ ' S, $043^{\circ} 11^{\prime} 09^{\prime}$ 'W; Figure 1). It has a surface area of $2.5 \mathrm{~km}^{2}$, volume of 6.5 million $\mathrm{mm}^{3}$ and a mean depth of about $4 \mathrm{~m}$. Rodrigo de Freitas Lagoon receives part of the local domestic and wastewater discharge coming from its drainage basin.

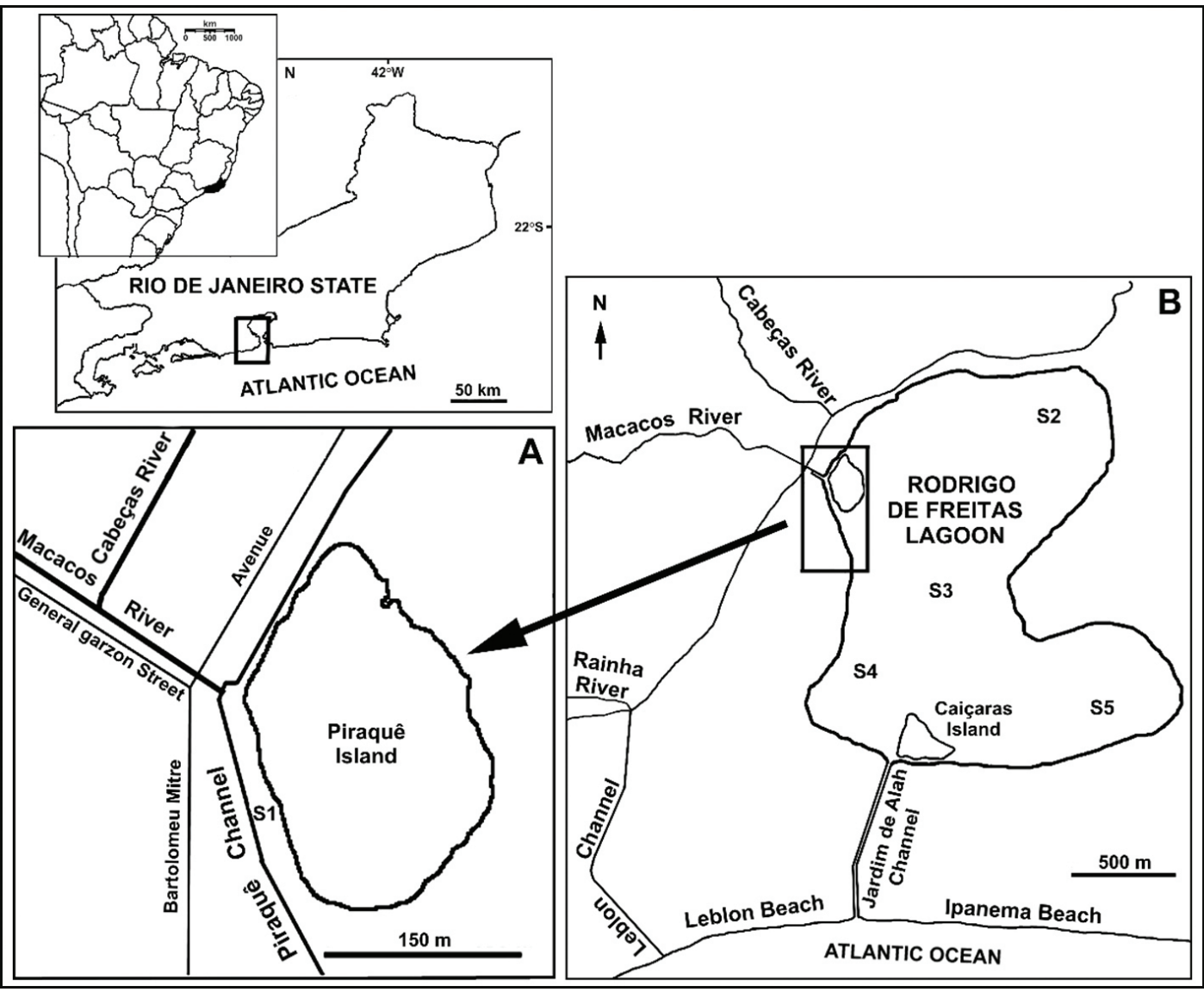

Figure 1. Location of Rodrigo de Freitas Lagoon and Piraquê Channel showing the sampling sites. 
The lagoon is connected to the sea by the Jardim de Alah Channel, and receives freshwater discharge from the Macacos and Cabeça rivers through the Piraquê Channel, situated on the northeastern side of the lagoon. The Piraquê Channel is shallower (maximum depth $\leq 2 \mathrm{~m}$ ) than the rest of lagoon, with low turbulence. Water residence time in this channel varies from hours to weeks due to the opening/closing of the artificial connection with the two rivers. Although this connection is irregular, it was open during most of this study.

\subsection{Monitoring and sampling}

Samples were collected monthly from March 2007 to March 2008 at one station (S1) located in the middle section of the Piraquê Channel (Figure 1A), and four stations (S2, S3, S4 and S5) in the main part of the lagoon (Figure 1B). Samples were obtained by passing a flask along the subsurface water, and were immediately fixed with $1 \%$ neutral Lugol solution. Subsamples were kept alive under refrigeration $\left(4^{\circ} \mathrm{C}\right)$. Water temperature and salinity (YSI-30 thermosalinometer), dissolved oxygen (YSI-54 oxymeter), and water transparency (Secchi disk) were measured weekly at $0.5 \mathrm{~m}$ intervals along the water column in the Piraquê Channel $\left(Z_{\max }=1.5 \mathrm{~m}\right)$ and in the lagoon $\left(Z_{\max }=4 \mathrm{~m}\right)$. The euphotic zone $\left(Z_{\text {eu }}\right)$ was calculated as three times the Secchi disk extinction depth (Cole, 1994). Data for precipitation and air temperature were obtained from a meteorological station located at the Jardim Botânico (http://www2.rio.rj.gov.br/georio/ site/alerta/alerta.htm).

\subsection{Morphology and taxonomic analysis}

Morphological analyses of live and fixed samples were carried out with the use of an Olympus BH2 phase-contrast microscope equipped with Image Pro Plus capture software, version 4.5.0.19® (Media Cybernetics, Inc., Silver Spring, MD, USA). For transmission electron microscopy (TEM), cells were concentrated by centrifugation and fixed for $2 \mathrm{~h}$ in $2.5 \%$ glutaraldehyde buffered with $0.1 \mathrm{M}$ sodium cacodylate ( $\mathrm{pH} 7.4)$. Then, the cells were rinsed three times with $0.1 \mathrm{M}$ sodium cacodylate buffer $(\mathrm{pH} 7.4)$ and post-fixed overnight in $1 \%$ osmium tetroxide buffered with $0.05 \mathrm{M}$ sodium cacodylate ( $\mathrm{pH} 7.4)$, dehydrated in ethanol, and embedded in Epon 812 (Pelco). Sections were placed on carbon-coated copper grids and double-stained for 40 min with $2 \%$ uranyl acetate and for $1 \mathrm{~min}$ with $1 \%$ lead citrate. The material was analysed and photographed in a ZEISS EM 900 at $80 \mathrm{kV}$. Taxonomic identification was based on morphological characteristics such as cell shape and size; number, colour, and shape of chloroplasts; presence of mucocysts; and ultrastructure of chloroplasts and pyrenoids, according to Hara and Chihara (1987).

\subsection{Temporal distribution and toxicity analysis of H. akashiwo}

Abundances of $H$. akashiwo (cells. $\mathrm{L}^{-1}$ ) were estimated from the Lugol samples by the settling technique, using an inverted microscope (Utermöhl, 1958) at 400× magnification. The biovolume $\left(\mathrm{mm}^{3} \mathrm{~L}^{-1}\right)$ was calculated according to
Edler (1979) and Hillebrand et al. (1999). Correlations between abiotic variables and $H$. akashiwo abundances were evaluated by Spearman's correlation analyses using Statistica 7.0 (StatSoft), considering data obtained in the surface of the Piraquê Channel and the main body of the Rodrigo de Freitas Lagoon $(\mathrm{N}=65)$. Prior to the analyses, all data sets were transformed logarithmically $[\ln (\mathrm{x}+1)]$.

The presence of brevetoxins and their derivatives was investigated in a sample taken during the bloom of $H$. akashiwo observed on 19 March 2007. A total of $1.5 \mathrm{~L}$ of water was gently filtered under vacuum onto a glass-fiber filter. The material retained on the filter was extracted in $100 \%$ methanol, concentrated in $\mathrm{N}_{2}$ flow, and then analysed by LC-MS on an Agilent 1200 liquid chromatograph system connected to a triple quadrupole mass spectrometer-ion-trap model 3200 Q-Trap (Applied Biosystems), equipped with a Turbo Spray ESI source. The system was calibrated with standard brevetoxins from NRC Canada. The compounds were separated by a rapid column chromatography reversed-phase Zorbax Eclipse XDB-C18, $4.6 \times 50 \mathrm{~mm}(1.8 \mu \mathrm{M})$ at $35^{\circ} \mathrm{C}$. For the chromatography, two mobile phases (A and B) were used, with a flow of $750 \mu \mathrm{L} \mathrm{min}^{-1}$ for $10 \mathrm{~min}$. Phase A consisted of $90 \%$ water and $10 \%$ acetonitrile, while phase B was $10 \%$ water and $90 \%$ acetonitrile, both with a concentration of $5 \mathrm{mM}$ ammonium formate and $53 \mathrm{mM}$ formic acid.

\section{Results}

\subsection{Morphology and taxonomic analysis of H. akashiwo}

Cells of $H$. akashiwo were solitary, although masses of immobile spherical cells surrounded by mucilage were observed on 19 March 2007 (Figure 2A-B). Cell shape varied from ovoid to elliptical, measuring 10.75-17.57 $\mu \mathrm{m}$ (maximum $=20.13 \mu \mathrm{m}, \mathrm{n}=40$ ) in length and 6.21-11.89 $\mu \mathrm{m}$ (maximum $=12.21 \mu \mathrm{m}, \mathrm{n}=40$ ) in width, with two unequal flagella inserted in anterior subapical depression. Chloroplasts were typically yellowish-brown, although greenish-yellow colouration was sometimes observed. The cells contained 8-18 discoid chloroplasts situated at the cell periphery and with thylacoids parallel to the cell surface (Figure 3A). Each chloroplast showed a bulging pyrenoid located in the inner end, with the pyrenoid matrix penetrated by thylakoids (Figure 3B). Many small spherical mucocysts (Figure 3B) were distributed along the periphery of the cell. The nucleus was situated in the middle part of the cell, sometimes in the upper portion (Figure 3C).

\subsection{Temporal distribution and toxicity investigation of H. akashiwo}

Two seasons (dry and rainy) occurred during the study period (Figure 4). The dry season (March through October 2007) was characterised by monthly precipitation between 0 and $84 \mathrm{~mm}$, with higher precipitation (186-269 mm) during the rainy season (November 2007 through March 2008). Although the water temperature was similar in the Piraquê Channel and the main body of the lagoon (Figure 5A, B), 


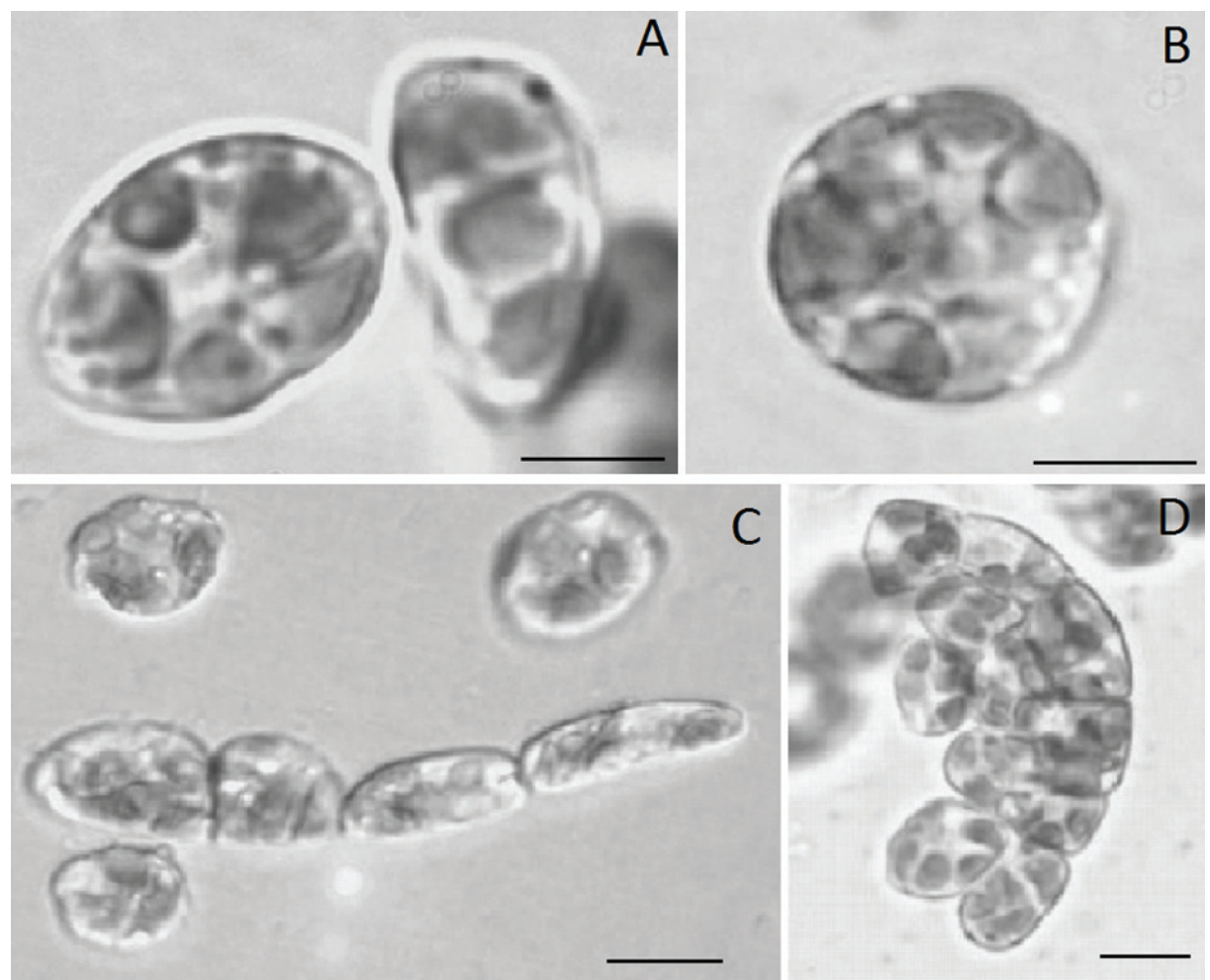

Figure 2. Light micrographs of living cells of Heterosigma akashiwo. (A) Solitary cells in ventral (left) and lateral (right) view. (B) Cell masses. Scale: $5 \mu \mathrm{m}$
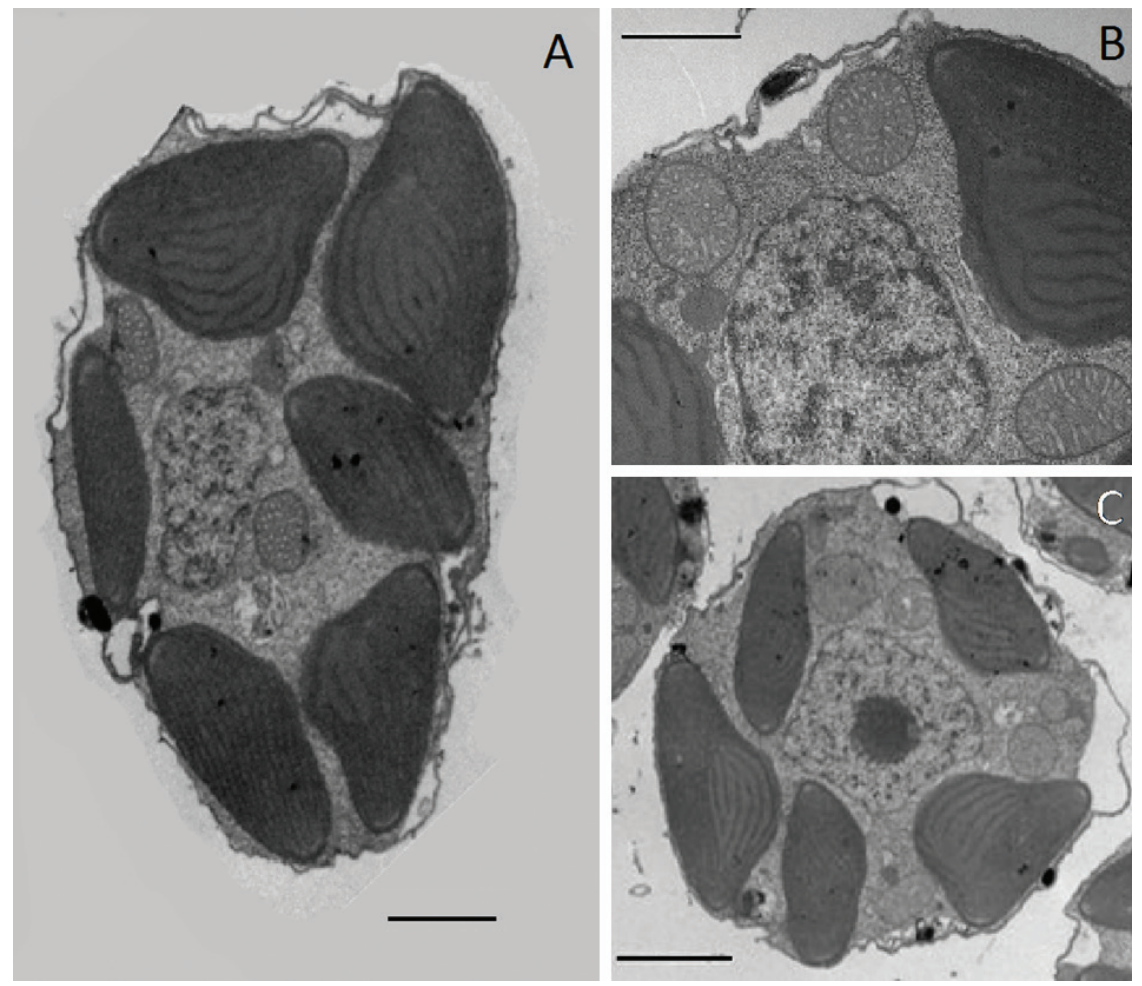

Figure 3. Transmission electron microscopy of Heterosigma akashiwo. (A) Longitudinal section of the whole cell. (B) Longitudinal section of the anterior part of a cell. (C) Cross section of a cell. Note the nucleus with a distinct nucleolus. $\mathrm{C}=$ Chloroplast. $\mathrm{P}=$ Pyrenoid. $\mathrm{M}=$ Mitochondrium. $\mathrm{N}=$ Nucleus. $\mathrm{n}=$ nucleolus. 


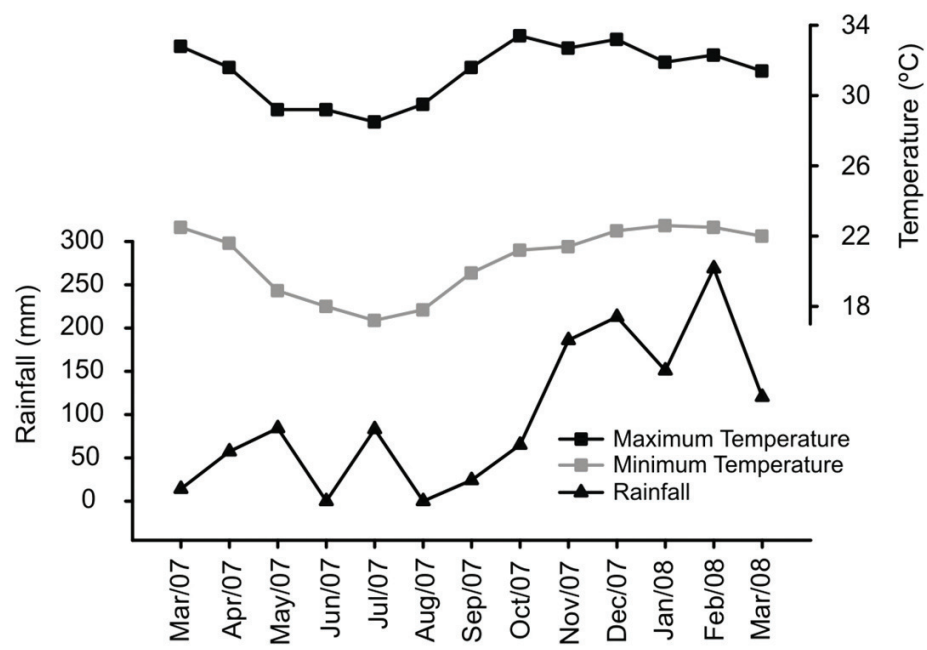

Figure 4. Seasonal fluctuations of mean air temperature $\left({ }^{\circ} \mathrm{C}\right)$ and total rainfall (mm) from March 2007 through March 2008.

CHANNEL

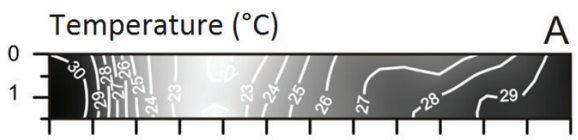

Salinity (psu)

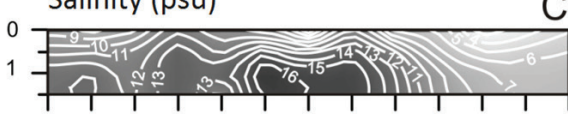

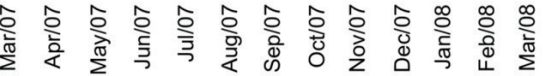

C
LAGOON
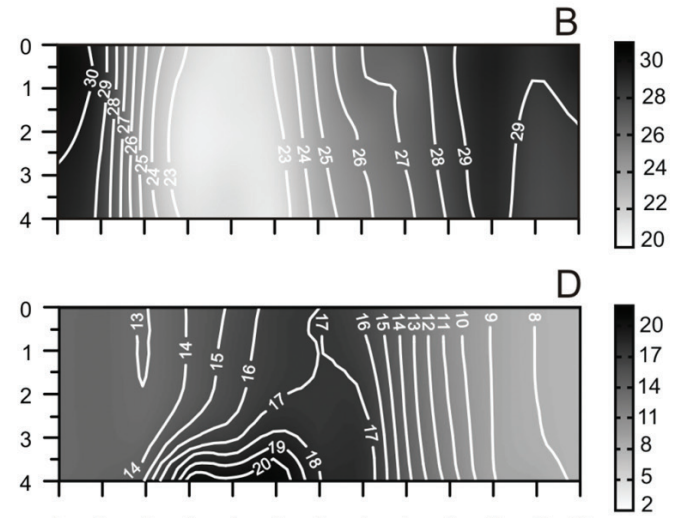

Figure 5. Temporal and vertical distribution of $(\mathrm{A}-\mathrm{B})$ temperature $\left({ }^{\circ} \mathrm{C}\right)$ and $(\mathrm{C}-\mathrm{D})$ salinity $(\mathrm{psu})$ recorded in the Piraquê Channel (left) and the main body of Rodrigo de Freitas lagoon (right) from March 2007 through March 2008. Values from the four sampling stations located in the main body of the lagoon were averaged.

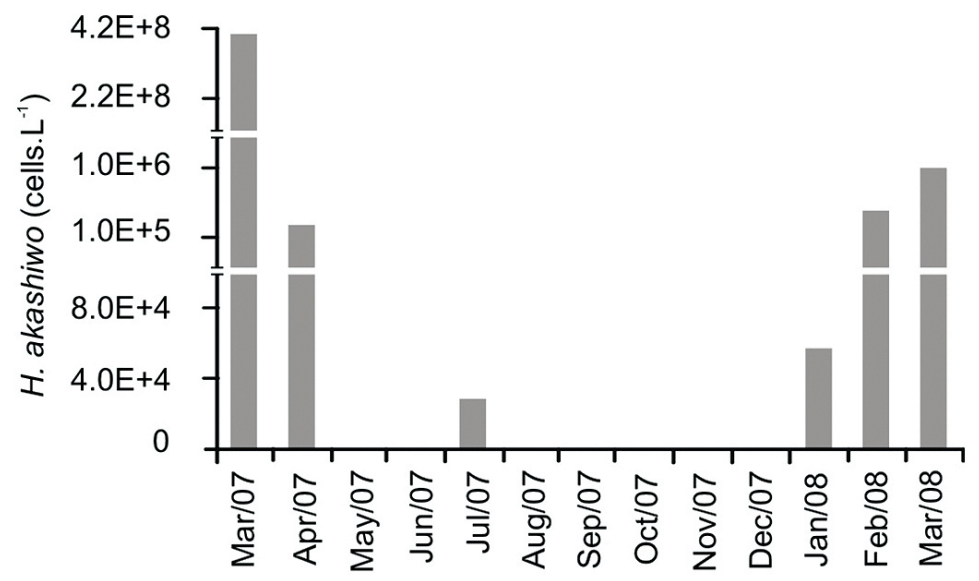

Figure 6. Heterosigma akashiwo abundances (cells. $\mathrm{L}^{-1}$ ) in the Piraquê Channel from March 2007 through March 2008. 
Table 1. Mean, minimum and maximum values of some abiotic variables in surface water of the Piraquê Channel and main body of the Rodrigo de Freitas Lagoon from March 2007 through March 2008. Values from the four sampling stations in the lagoon were averaged.

\begin{tabular}{lcccc}
\hline & \multicolumn{2}{c}{ Channel } & \multicolumn{2}{c}{ Lagoon } \\
\hline & Mean & Min-Max & Mean & Min-Max \\
\hline Temperature $\left({ }^{\circ} \mathrm{C}\right)$ & 26.5 & $20.4-22.5$ & 27.8 & $21.4-31.5$ \\
Dissolved oxygen $\left(\mathrm{mg} \mathrm{L}^{-1}\right)$ & 4.8 & $0-11.5$ & 8.4 & $4.9-13.9$ \\
Salinity (psu) & 7 & $0-16.8$ & 12.5 & $7.2-17.2$ \\
Maximum euphotic zone (m) & depth & $1.2-$ depth & 1.8 & $1.5-2.7$ \\
Depth (m) & 1 & $0.8-1.5$ & 3.9 & $3-4$ \\
\hline
\end{tabular}

Table 2. Abundances and biovolumes of H. akashiwo during blooms observed in Piraquê Channel from March 2007 through March 2008. Values of water temperature, dissolved oxygen (DO), salinity, Secchi disk depth, and depth of the euphotic zone $($ Zeu/Zmax) are also shown. n.d. = not determined.

\begin{tabular}{cccccccc}
\hline Date & Abundance & Biovolume & Temperature & DO & \multicolumn{2}{c}{ Salinity } & \multicolumn{2}{c}{ Secchi disk } & Depth max. \\
\hline & $\left(\right.$ cells. $\left.\mathbf{L}^{-\mathbf{1}}\right)$ & $\left(\mathbf{m m}^{\mathbf{3}} \mathbf{L}^{-\mathbf{1}}\right)$ & $\left(\mathbf{}{ }^{\circ} \mathbf{C}\right)$ & $\mathbf{( \mathbf { m g ~ L } ^ { - 1 } )}$ & $\mathbf{( p s u})$ & $\mathbf{( m )}$ & $\mathbf{( m )}$ \\
\hline $19 / 03 / 07$ & $4.0 \times 10^{8}$ & 115.292 & 28.4 & 3.5 & 7.5 & 0.6 & n.d. \\
$24 / 04 / 07$ & $1.6 \times 10^{6}$ & 0.462 & 29.5 & 1.6 & 8.4 & 0.4 & 1 \\
$09 / 07 / 07$ & $2.8 \times 10^{4}$ & 0.008 & 24.5 & 5.0 & 14.4 & n.d. & n.d. \\
$14 / 01 / 08$ & $5.7 \times 10^{4}$ & 0.016 & 29.0 & 5.5 & 1.6 & 0.7 & 0.8 \\
$18 / 02 / 08$ & $3.7 \times 10^{6}$ & 1.073 & 30.7 & 2.7 & 5.2 & 0.7 & 0.8 \\
$17 / 03 / 08$ & $1.0 \times 10^{7}$ & 2.859 & 27.7 & 7.3 & 7.0 & 0.5 & 0.8 \\
\hline
\end{tabular}

different patterns were observed in these compartments regarding salinity and DO (Figure $5 \mathrm{C}, \mathrm{F}$ ). Compared to the main body of the lagoon, the Piraque Channel had low DO (4-6 mg L ${ }^{-1}$ ) and salinity (2-11 psu) at the surface, the latter resulting in the formation of a permanent halocline.

Six blooms of $H$. akashiwo were detected during the study period (Figure 6). These blooms were observed only in the Piraquê Channel, within a salinity range of 1.6-14.4 psu and water temperature of 24.4-30.9 ${ }^{\circ} \mathrm{C}$. Heterosigma akashiwo was not found in other sampling stations in the lagoon. The highest $H$. akashiwo abundance in Piraquê Channel $\left(4 \times 10^{8}\right.$ cells. $\left.\mathrm{L}^{-1}\right)$ was observed on 19 March 2007 , with salinity and temperature of 7.5 and $28.4{ }^{\circ} \mathrm{C}$, respectively. Heterosigma akashiwo was the dominant species in the phytoplankton community only in March 2007; in other months, the cyanobacteria Pseudanabaena catenata, P. galeata and Synechocystis salina were dominant (Branco et al., 2010. Data for environmental variables of the lagoon and the channel, and for density and biovolume of $H$. akashiwo cells during the six bloom events are shown in Tables 1 and 2, respectively. Spearman's rank correlation analyses indicated that $H$. akashiwo was negatively correlated with water depth $(\mathrm{R}=-0.48 ; p<0.001)$ and salinity $(\mathrm{R}=-0.30 ; p=0.011)$.

Brevetoxins and derivatives were not detected in the extract obtained during the bloom on 19 March 2007.

\section{Discussion}

Identification of $H$. akashiwo based on morphological characters is not always easy, considering their small, pleomorphic cells. Furthermore, H. akashiwo can be confused with Olisthodiscus luteus N. Carter; these species are separated by cell morphology and ultrastructure. While O. luteus has fewer chloroplasts (5-13), which are absent from the ventral region of the cell, and lack mucocysts and thylakoid lamellae in the matrix of the pyrenoid (Hara and Chihara, 1987; Hallegraeff and Hara, 1995), H. akashiwo shows mucocysts and has more chloroplasts (10 - 30) distributed on the periphery of the cell, with thylakoid lamellae penetrating the matrix of the pyrenoid (Hara et al., 1985; Hara and Chihara, 1987). Recent studies of molecular biology suggest that Heterosigma includes only the species H. akashiwo, distinct from Olisthodiscus and other raphidophyte genera (Connell, 2000; Bowers et al., 2006; Yamaguchi et al., 2010). Heterosigma is also very close to the genus Chlorinimonas Yamaguchi, Nakayama, Murakami \& Inouye; however, the absence of thylakoid invagination into the pyrenoid matrix distinguishes the latter genus from Heterosigma (Yamaguchi et al., 2010).

Cells of H. akashiwo occurring in the Rodrigo de Freitas Lagoon were similar to the descriptions and illustrations of this species by Hara et al. (1985) and Hara and Chihara (1987). Many of the cells from the population collected on 19 March 2007 showed numbers and distribution of chloroplasts (data not shown) similar to those found in $O$. luteus, sometimes with colour (greenish-yellow) and number of chloroplasts (data not shown) resembling cells of Chlorinimonas, which may contribute to misidentification of species. However, the chloroplasts showed the same ultrastructural features described for H. akashiwo by Hara and Chihara (1987).

Blooms of $H$. akashiwo are usually recorded at salinities between 20 and 35, reaching an optimum at approximately 20-25 psu (Honjo, 1993; Kempton et al., 2008; Martinez et al., 2010). However, formation of $H$. akashiwo blooms has 
been also associated with freshwater runoff, usually followed by a reduction in salinity to values $<15 \mathrm{psu}$ (Taylor and Haigh, 1993), and the stratification of the water column (Yamochi, 1989). During this study, blooms of H. akashiwo occurred within a salinity range of 1.6-14.4 psu, in agreement with the tolerance of this species to low salinities previously reported in the literature (Zhang et al. 2006, Fredrickson et al. 2011, Strom et al., 2013). In the studied period, the freshwater runoff from the rivers likely contributed to the decrease of salinity in the surface water of the Piraquê Chanel, resulting in a permanent halocline. This would explain the absence of $H$. akashiwo blooms in the main body of the lagoon, where the salinity was usually higher and homogeneously distributed through the water column. Previous studies based on field and cultured material have revealed that different populations or strains of Heterosigma species show different optimum salinity levels, and their growth responses to a variety of ecological factors are also different (Honjo, 1993; Smayda, 1998; Han et al., 2002; Fredrickson et al., 2011). Moreover, the broad salinity tolerance of $H$. akashiwo appears to provide a refuge through a number of mechanisms that act to reduce predation and promote net growth of $H$. akashiwo populations, e.g. ability of this species to accumulate and grow in low-salinity layers inhospitable to the predator (Strom et al., 2013).

Heterosigma akashiwo has an alternating pelagicbenthic life history (Tomas 1978; Smayda, 1998). Benthic stages (resting cells and cysts) allow the species to survive under unfavourable environmental conditions, especially low water temperatures and dark conditions (Han et al., 2002; Shikata et al., 2007). Resting cells differ from cysts because they do not require a maturation period for germination. Moreover, resting cells are surrounded by an external sticky polysaccharide calyx, and although they are immobile, retain the flagellum (Han et al., 2002); sometimes these cells consist of agglutinated masses of brown, non-motile cells (Tomas, 1978; Smayda, 1998). Cysts are generally spherical, without a flagellum, surrounded by mucilaginous materials, and have a mandatory period of dormancy (Itakura et al., 1996). Cells of H. akashiwo forming masses of immobile cells surrounded by mucilage, detected during this study, were similar to resting cells described by Tomas (1978), based on cultured material. According to this author, resting cells were viable in the dark for 15 weeks at temperatures between 5 and $10^{\circ} \mathrm{C}$, but they died at temperatures higher than $15^{\circ} \mathrm{C}$. Han et al. (2002) demonstrated that induction of the resting-cell stage in batch cultures of $H$. akashiwo is more effective in conditions of light deprivation and low temperatures (below $10^{\circ} \mathrm{C}$ ). Field studies have also indicated that temperature is a critical determinant for the induction of resting cells in H. akashiwo (Taylor and Haigh, 1993; Imai and Itakura, 1991, 1999). Resting stages of H. akashiwo can germinate at low temperatures and under low light intensity; however the species requires both high temperature and strong light for survival and immediate growth of the germinated cells (Shikata et al., 2008). During the period when resting cells were found in the Piraquê Channel, the water temperature was $28.4{ }^{\circ} \mathrm{C}$ from the surface to bottom, and the data for the Secchi disk and euphotic zone indicated availability of light at the bottom of the channel. Since resting cells of $H$. akashiwo were not found in sediment samples (Branco, 2009), we could infer that resting cells were resuspended in the water column from the bottom, allowing immediate germination and rapid growth of vegetative cells (Shikata et al., 2008).

Brevetoxins and their derivatives were not detected during this study. Nor were fish kills associated with blooms of H. akashiwo. The lack of fish kills contrasts with reports from southern Brazil, where H. akashiwo blooms were associated with mass mortality of fish (Proença and Fernandes, 2004). The absence of toxicity to fish observed during this study, may be related to the high temperatures observed during the blooms of $H$. akashiwo $\left(27.7\right.$ to $\left.30.9^{\circ} \mathrm{C}\right)$, which could have inhibited or minimised the toxicity of this species (Ono et al., 2000). However, low salinity, as recorded during the bloom events in Piraquê Channel, also apparently greatly enhances toxin production in this species (Haque and Onoue, 2002). On the other hand, recent studies have not detected brevetoxin in H. akashiwo, confirming the existence of variability in different circumstances (Lewittus and Holland, 2003; Zhang et al., 2004). Various environmental factors including temperature, salinity, and nutrient availability, have been associated with variable H. akashiwo toxicity (Fredrickson et al., 2011). High levels of genetic and phenotypic variability have been recorded within regional populations of $H$. akashiwo, suggesting the existence of distinct ecotypes, which may be related to different factors such as the geographic origin of the population and the timing of the bloom (Fredrickson et al., 2011).

However, brevetoxin is not the only factor related to the toxicity of $H$. akashiwo. Other mechanisms such as mechanical anoxia, hemolytic compounds, and reactive oxygen substances are also associated with the harmful effects of H. akashiwo (Kuroda et al., 2005; Marshall et al., 2005; Ling and Trick, 2010). Moreover, although the blooms may not act directly on the fish, they can be harmful to many organisms including copepods, ciliates, larvae and adults of oysters, shrimps, and scallops (Clough and Strom, 2005; Wang et al., 2006; Yu et al., 2010), affecting different trophic levels.

In short, our results indicated that the low depth of the water column and the low salinity could have been the main factors driven H. akashiwo blooms observed in the Piraquê Channel during this study. The depth could explain better blooms of H. akashimo on Channel Piraquê for allowing light input throughout the water column. Thus, most likely the light is the factor controlling bloom formation and not the depth. These findings also showed the need for more accurate studies on the dynamics of $H$. akashiwo populations occurring in this compartment of the Rodrigo de Freitas Lagoon due to their potential harm to fish stocks and consequent economic and environmental impacts. 


\section{Acknowledgements}

This paper was funded by grants from the Conselho Nacional de Desenvolvimento Científico e Tecnológico to S. B. (No. 132826/2010-0) and M. M. (No. 305655/ 2006-0; 304908/2009-6); and by the Fundação de Amparo à Pesquisa do Estado do Rio de Janeiro to M. M. (E-26/ 171.413/2006). We thank the technical staff of the Instituto Estadual do Ambiente (INEA) for sampling help, and Dr. Janet W. Reid for improving the English.

\section{References}

BOWERS, HA., TOMAS, C., TENGS, T., KEMPTON, JW., LEWITUS, AJ. and OLDACH, DW., 2006. Raphidophyceae [Chadefaud ex Silva] systematics and rapid identification: sequence analyses and real-time PCR assays. Journal of Phycology, vol. 42, no. 6, p. 1333-1348. http://dx.doi.org/10.1111/j.15298817.2006.00285.x. PMid:20411032

BRANCO, S., MENEZES, M. and DOMINGOS, P., 2010. Flagellate blooms in Rodrigo de Freitas Lagoon, Rio de Janeiro, Brazil. In Proceedings of the Thirteenth International Conference on Harmful Algae, 2008. Hong Kong. Hong Kong: CHN. p. 8-13.

BRANCO, S., 2009. Algas flageladas no Canal do Piraquê da Lagoa Rodrigo de Freitas, com ênfase nas espécies potencialmente nocivas. Rio de Janeiro: Universidade Federal do Rio de Janeiro. 32 p. Monografia em Biologia Vegetal.

CLOUGH, J. and STROM, S., 2005. Effects of Heterosigma akashiwo (Raphidophyceae) on protist grazers: laboratory experiments with ciliates and heterotrophic dinoflagellates. Aquatic Microbial Ecology, vol. 39, p. 121-134. http://dx.doi. org/10.3354/ame039121.

COLE, GA., 1994. Textbook of limnology. 4th ed. Illinois: Prospect Heights, Waveland Press. 426 p.

CONNELL, L., WELLING, KA. and CATTOLICO, RA., 1997. Algal organic metabolites affect survival of Pacific oyster, Crassostrea gigas, larvae. Journal of Shellfish Research, vol. 16, p. 493-501.

CONNELL, LB., 2000. Nuclear ITS region of the alga Heterosigma akashiwo (Chromophyta, Raphidophyceae) is identical in isolates from Atlantic and Pacific basins. Marine Biology, vol. 136, no. 6, p. 953-960. http://dx.doi.org/10.1007/s002270000314.

EDLER, L., 1979. Recommendations for marine biological studies in the Baltic Sea, phytoplankton and chlorophyll. UNESCO, Working Group 11, Baltic Marine Biologists. 38 p.

FREDRICKSON, KA., STROM, SL., CRIM, R. and COYNE, K., 2011. Interstrain variability in physiology and genetics of Heterosigma akashiwo (Raphidophyceae) from the west coast of North America. Journal of Phycology, vol. 47, no. 1, p. 25-35. http://dx.doi.org/10.1111/j.1529-8817.2010.00942.x.

HALLEGRAEFF, GM. and HARA, Y.,1995. Taxonomy of harmful marine raphidophytes. In HALLEGRAEFF, GM., ANDERSON, DM. and CEMBELLA, A. (Eds.). Manual on Harmful Marine Microalgae. Paris: IOC UNESCO. p. 365-371.

HAN, MS., KIM, YP. and CATTOLICO, RA., 2002. Heterosigma akashiwo (Raphidophyceae) resting cell formation in batch culture: strain identity versus physiological response. Journal of Phycology, vol. 38 , no. 2, p. 304-317. http://dx.doi.org/10.1046/j.15298817.2002.01087.x
HAQUE, SM. and ONOUE, Y., 2002. Effects of salinity on growth and toxin production of a noxious phytoflagellate, Heterosigma akashiwo (Raphidophyceae). Botanica Marina, vol. 45, no. 4, p. 356-363. http://dx.doi.org/10.1515/BOT.2002.036.

HARA, Y. and CHIHARA, M., 1987. Morphology, ultrastructure and taxonomy of the raphidophycean alga Heterosigma akashiwo. Botanical Magazine, vol. 100, no. 2, p. 151-163. http://dx.doi. org/10.1007/BF02488320.

HARA, Y., INOUYE, I. and CHIHARA, M., 1985. Morphology, Ultrastructure of Olisthodiscus luteus (Raphidophyceae) with Special Reference to the Taxonomy. Botanical Magazine, vol. 98, no. 3, p. 251-262. http://dx.doi.org/10.1007/BF02488775.

HILLEBRAND, H., DÜRSELEN, CD., KIRSCHTEL, D., POLLINGHER, D. and ZOHARY, T., 1999. Biovolume calculation for pelagic and benthic microalgae. Journal of Phycology, vol. 35 , no. 2 , p. 403-424. http://dx.doi.org/10.1046/j.15298817.1999.3520403.x

HONJO, T., 1993. Overview on bloom dynamics and physiological ecology of Heterosigma akashiwo. In SMAYDA, T.J. and SHIMIZU, Y. (Eds.). Toxic Phytoplankton Blooms in the Sea. Amsterdam: Elsevier. p. 33-41.

IMAI, I. and ITAKURA, S., 1991. Densities of dormant cells of the red tide flagellate Heterosigma akashiwo (Raphidophyceae) in bottom sediments of northern Hiroshima Bay, Japan. Bulletin of Japanese Society of Microbiology and Ecology, vol. 6, no. 1, p. 1-7. http://dx.doi.org/10.1264/microbes1986.6.1.

IMAI, I. and ITAKURA, S., 1999. Importance of cysts in the population dynamics of the red tide flagellate Heterosigma akashiwo (Raphidophyceae). Marine Biology, vol. 133, no. 4, p. 755-762. http://dx.doi.org/10.1007/s002270050517.

ITAKURA, S., NAGASAKI, K., YAMAGUCHI, M. and IMAI, I., 1996. Cyst formation in the red tide flagellate Heterosigma akashiwo (Raphidophyceae). Journal of Plankton Research, vol. 18, no. 10, p. 1975-1979. http://dx.doi.org/10.1093/plankt/18.10.1975.

KEMPTON, J., KEPPLER, CJ., LEWITUS, A., SHULER, A. and WILDE, S., 2008. A novel Heterosigma akashiwo (Raphidophyceae) bloom extending from a South Carolina bay to offshore waters. Harmful Algae, vol. 7, no. 2, p. 235-240. http:// dx.doi.org/10.1016/j.hal.2007.08.003.

KEPPLER, CJ.,HOGUET, J., SMITH, K., RINGWOOD, AH. and LEWITUS, AJ., 2005. Sublethal effects of the toxic alga Heterosigma akashiwo on the southeastern oyster (Crassostrea virginica). Harmful Algae, vol. 4, no. 2, p. 275-285. http://dx.doi. org/10.1016/j.hal.2004.05.002.

KHAN, S., ARAKAWA, O. and ONOUE, Y., 1997. Neurotoxins in a toxic red tide of Heterosigma akashiwo (Raphidophyceae) in Kagoshima Bay, Japan. Aquatic Research, vol. 28, no. 1, p. 9-14. http://dx.doi.org/10.1111/j.1365-2109.1997.tb01309.x.

KURODA, A., NAKASHIMA, T., YAMAGUCHI, K. and ODA, T., 2005. Isolation and characterization of light-dependent hemolytic cytotoxin from harmful red tide phytoplankton Chattonella marina. Comparative Biochemistry and Physiology Part C Toxicology \& Pharmacology, vol. 141, no. 3, p. 297-305. http://dx.doi. org/10.1016/j.cca.2005.07.009. PMid:16098818

LEWITTUS, AJ. and HOLLAND, AF., 2003. Initial Results From a Multi-Institutional Collaboration for Monitoring Harmful Algal Bloooms in South Carolina in Coastal Monitoring Through Partnerships. In MELZIAN, BD., ENGLE, V., MCALISTER, M. and SANDHU, S. (Eds.). Proceedings of the Fifth Symposium 
on the Enviromental Monitoring and Assessment Program, 2003. p. 361-371.

LING, C. and TRICK, CG., 2010. Expression and standardized measurement of hemolytic activity in Heterosigma akashiwo. Harmful Algae, vol. 9, no. 5, p. 522-529. http://dx.doi.org/10.1016/j. hal.2010.04.004.

MAFRA, LL., 2005. Microalgas nocivas e ficotoxinas no complexo estuarino de Paranaguá: subsídios para o monitoramento. Curitiba: Universidade Federal do Paraná. 156 p. Dissertação de Mestrado em Botânica.

MARSHALL, J-A., SALAS, M., ODA, T. and HALLEGRAEFF, G., 2005. Superoxide production by marine microalgae I. Survey of 37 species from 6 classes. Marine Biology, vol. 147, no. 2, p. 533-540. http://dx.doi.org/10.1007/s00227-005-1596-7.

MARTINEZ, R., ORIVE, E., LAZA-MARTINEZ, A. and SEOANE, S., 2010. Growth response of six strains of Heterosigma akashiwo to varying temperature, salinity and irradiance conditions. Journal of Plankton Research, vol. 32, no. 4, p. 529-538. http://dx.doi. org/10.1093/plankt/fbp135.

NAKAMURA, A., OKAMOTO, T., KOMATSU, N., OOKA, S., ODA, T., ISHIMATSU, A. and MURAMATSU, T., 1998. Fish mucus stimulates the generation of superoxide anion by Chattonella marina and Heterosigma akashiwo. Fisheries Science, vol. 64, p. 866-869.

O'HALLORAN, C., SILVER, MW., HOLMAN, TR. and SCHOLIN, CA., 2006. Heterosigma akashiwo in central California waters. Harmful Algae, vol. 5, no. 2, p. 124-132. http://dx.doi. org/10.1016/j.hal.2005.06.009.

ONO, K., KHAN, S. and ONOUE, T., 2000. Effects of temperature and light intensity on the growth and toxicity of Heterosigma akashiwo (Raphidophyceae). Aquatic Research, vol. 31, no. 5, p. 427-433. http://dx.doi.org/10.1046/j.1365-2109.2000.00463.x.

PROENÇA, LAO. and FERNANDES, LF., 2004. Introdução de microalgas no ambiente marinho: impactos negativos e fatores controladores. In SILVA, JSV. and SOUZA, RCCL. (Eds.). Água de Lastro e Bioinvasão. Rio de Janeiro: Interciência. p. 77-97.

PROENÇA, LAO., FONSECA, RS. and PINTO, TO., 2011. Microalgas em áreas de cultivo do litoral de Santa Catarina. São Carlos: Rima. 80 p.

JACK RENSEL, JE.,HAIGH, N. and TYNAN, TJ., 2010. Fraser River sockeye salmon marine survival decline and harmful blooms of Heterosigma akashiwo. Harmful Algae, vol. 10, no. 1, p. 98115. http://dx.doi.org/10.1016/j.hal.2010.07.005.

SHIKATA, T., NAGASOE, S., MATSUBARA, T., YAMASAKI, Y., SHIMASAKI, Y., OSHIMA, Y. and HONJO, T., 2007. Effects of temperature and light on cyst germination and germinated cell survival of the noxious raphidophyte Heterosigma akashiwo. Harmful Algae, vol. 6, no. 5, p. 700-706. http://dx.doi.org/10.1016/j. hal.2007.02.008.

SHIKATA, T., NAGASOE, S., MATSUBARA, T., YOSHIKAWA, S., YAMASAKI, Y., SHIMASAKI, Y., OSHIMA, Y., JENKINSON, IR. and HONJO, T., 2008. Factors influencing the initiation of blooms of the raphidophyte Heterosigma akashiwo and the diatom Skeletonema costatum in a port in Japan. Limnology and Oceanography, vol. 53, no. 6, p. 2503-2518. http://dx.doi. org/10.4319/lo.2008.53.6.2503.

SMAYDA, T., 1998. Ecophysiology and bloom dynamics of Heterosigma akashiwo (Raphidophyceae). In ANDERSON, DM., CEMBELLA, AD. and HALLEGRAEFF, GM. (Eds.).
Physiological Ecology of Harmful Algal Blooms. Berlin: SpringerVerlag. p. 113-131.

STROM, SL., HARVEY, EL., FREDRICKSON, KA. and MENDEN-DEUER, S., 2013. Broad salinity tolerance as a refuge from predation in the harmful raphidophyte alga Heterosigma akashiwo (Raphidophyceae). Journal of Phycology, vol. 49, no. 1, p. 20-31. http://dx.doi.org/10.1111/jpy.12013.

TAYLOR, FJR. and HAIGH, R., 1993. The ecology of fish-killing blooms of the chloromonad flagellate Heterosigma akashiwo in the Strait of Georgia and adjacent waters. In SMAYDA, TJ. and SHIMIZU, Y. (Eds.). Toxic Phytoplankton Blooms in the Sea. Amsterdam: Elsevier. p. 705-710.

TOMAS, CR., 1978. Olisthodiscus luteus (Chrysophyceae). II. Formation and survival of a benthic stage. Journal of Phycology, vol. 14, no. 3, p. 314-319. http://dx.doi.org/10.1111/j.1529-8817.1978. tb00304.x.

UTERMÖHL, H., 1958. Zur Vervöllkommnung der quantitativen Phytoplankton-Methodik. Mitteilungen der Internationale Vereinigung für Theoretische und Angewandte Limnologie, vol. 9, p. 1-38.

WANG, L., YAN, T. and ZHOU, M., 2006. Impacts of HAB species Heterosigma akashiwo on early development of the scallop Argopecten irradians Lamarck. Aquaculture (Amsterdam, Netherlands), vol. 255, no. 1-4, p. 374-383. http://dx.doi. org/10.1016/j.aquaculture.2005.11.057.

YAMAGUCHI, H., NAKAYAMA, T., MURAKAMI, A. and INOUYE, I., 2010. Phylogeny and taxonomy of the Raphidophyceae (Heterokontophyta) and Chlorinimonas sublosa gen. et sp. nov., a new marine sand-dwelling raphidophyte. Journal of Plant Research, vol. 123, no. 3, p. 333-342. http://dx.doi.org/10.1007/ s10265-009-0281-1. PMid:19946727

YAMOCHI, S., 1989. Mechanisms for outbreak of Heterosigma akashiwo red tide in Osaka Bay, Japan. In OKAICHI, X., ANDERSON, R. and NEMOTO, X. (Eds.). Red Tides: Biology, Environmental Science, and Toxicology. New York: Elsevier. p. 253-256.

YU, J., YANG, G. and TIAN, J., 2010. The effects of the harmful alga Heterosigma akashiwo on cultures of Schmackeria inopinus (Copepoda, Calanoida). Journal of Sea Research, vol. 64, no. 3, p. 287-294. http://dx.doi.org/10.1016/j.seares.2010.04.002.

ZHANG, C., GLASGOW, HB., MOELLER, PDR., BURKHOLDER, JM., LEWITUS, AJ., MELIA, GM., MORTON, SL. and ALLEN, EH., 2004. Evaluation of Toxicity in Nine Raphidophyte Strains Isolated from Different Geographic Regions. In STEIDINGER, KA., LANDSBERG, JH., TOMAS, CR. and VARGO, GA. (Eds.). Proceedings of the Xth International Conference on Harmful Algae, 2004. Petersburg, Florida: Florida Fish and Wildlife Conservation Commission, Florida Institute of Oceanography, and Intergovernmental Oceanographic Commission of UNESCO. p. $198-200$.

ZHANG, Y., FU, F-X.,WHEREAT, E., COYNE, KJ. and HUTCHINS, DA., 2006. Bottom -up controls on a mixed-species HAB assemblage: A comparison of sympatric Chattonella subsalsa and Heterosigma akashiwo (Raphidophyceae) isolates from the Delaware Inland Bays, USA. Harmful Algae, vol. 5, no. 3, p. 310-320. http://dx.doi.org/10.1016/j.hal.2005.09.001. 